\title{
ANALISIS PENGARUH BRAND AWARENESS, PRODUCT QUALITY DAN EASE OF USE TERHADAP CUSTOMER PERCEIVED VALUE PADA E- MONEY MANDIRI E-TOLL CARD
}

\author{
Basrah Saidani \\ Fakultas Ekonomi Universitas Negeri Jakarta \\ Email: basrah_sp@yahoo.com \\ Laksmi Anggana Raras \\ Fakultas Ekonomi Universitas Negeri Jakarta \\ Email: laksmiangganar28@gmail.com \\ Shandy Aditya \\ Fakultas Ekonomi Universitas Negeri Jakarta \\ Email: shandy@unj.ac.id
}

\begin{abstract}
ABSTRAK
Penelitian ini bertujuan untuk mengetahui hubungan positif dari masing-masing variabel independen dalam hal ini Brand Awareness, Product Quality dan Ease of Use terhadap variabel dependen Customer Perceived Value. Dengan mengambil responden secara Purposive sampling 200 pengguna E-Money Mandiri E-Toll Card di wilayah JABODETABEK dengan $\geq 17$ tahun sebagai sampel, kasus ini akan menarik karena pemerintah sedang mencoba untuk menerapkan budaya Fintech dan kewajiban untuk menggunakan uang elektronik di tol jalan. Pengumpulan data dilakukan dengan metode survei menggunakan regresi berganda dan analisis data diuji dengan menggunakan SPSS. Hasilnya menunjukkan bahwa Kesadaran Merek, Kualitas Produk, Kemudahan Penggunaan memiliki efek positif pada Nilai Persepsi Pelanggan.
\end{abstract}

Kata kunci: Brand Awareness, Product Quality, Ease of Use, Customer Perceived Value. 


\section{PENDAHULUAN}

\section{Latar Belakang Masalah}

Kebutuhan masyarakat modern yang tidak terbatas ruang dan waktu memotivasi setiap wilayah tak terkecuali Indonesia untuk selalu mengejar kemajuan teknologi di bidang keuangan, karena Fintech perlahan membentuk dan merubah ekosistem jasa keuangan yang lebih baik dan luas kedepannya.

Salah satu tren yang dipengaruhi oleh revolusi Fintech adalah terbentuknya budaya Cashless yang sistem transaksinya dilakukan secara non-tunai/sistem digital. Dalam menanggapi Fintech, Pemerintah menerapkan elektronifikasi tol $100 \%$ pada Gerbang tol sehingga transaksi menjadi cepat, praktis dan nyaman serta meningkatkan efisiensi dan kualitas layanan pada sistem pembayaran.

Bank Mandiri menjadi salah satu bank yang di beri kewenangan dalam menerbitkan uang elektronik berupa chip yang ditanam dalam kartu, dan berhasil memperoleh ranking tertinggi 29.8\% pada Brand E-toll di tahun 2018 (Top Brand Index, 2018) merupakan Customer Perceived Value. Namun diketahui motivasi pemakaian kartu bagi pengguna E-Money yang didasari oleh aspek promosi dari penjual maupun bank hanya disuarakan oleh 20,22 persen dan 20,10 persen responden (Purnamasari, 2017)

Penerimaan merek oleh konsumen di rasa masih kurang karena masyarakat menggunakan kartu didasari ketersediaan kartu pada GTO (CNN, 2017) dan Emoney Mandiri dengan E-toll-nya terlebih dahulu bekerjasama dengan pihak toll (Kontan, 2017) Permasalahan tersebut mewakili variabel Brand Awareness.

Selanjutnya pada variabel Product Quality, E-money mandiri E-toll card tidak memerlukan pin transaksi sehingga mudah dipindahtangankan, namun jika kartu hilang maka saldo pun hilang. Dan banyak ditemukan produk yang diragukan originalitas dan kualitasnya karena sering dijumpai E-money yang dijual diluar bank Mandiri dan merchant resmi (Mandiri, 2017). Lalu pelanggan mengeluhkan terpotongnya saldo double dalam sekali transaksi. (Ramadhan dan Muslimah, 2018)

E-toll sulit digunakan karena alat reader tidak peka dalam mendetekasi kartu (Firmansyah dan Susanto, 2017). Selanjutnya pengecekan saldo sulit karena 
hanya dapat dilakukan dengan menyimpan bukti struk terakhir serta menggunakan hp yang dapat mensupport aplikasi e-money info yaitu android dengan perangkat NFC, sehingga manfaat aplikasi belum dapat dirasakan seluruh pengguna secara luas. (Bank Mandiri, 2013)

\section{Perumusan Masalah}

1. Apakah terdapat pengaruh positif Brand Awareness terhadap customer perceived value E-money Mandiri e-toll card?

2. Apakah terdapat pengaruh positif Product Quality terhadap customer perceived value E-money Mandiri e-toll card?

3. Apakah terdapat pengaruh positif Ease of Use terhadap customer perceived value E-money Mandiri e-toll card?

\section{Tujuan Penelitian}

1. Untuk menguji secara empiris adanya pengaruh positif Brand awareness terhadap Customer Perceived Value.

2. Untuk menguji secara empiris adanya pengaruh positif Product Quality terhadap Customer Perceived Value.

3. Untuk menguji secara empiris adanya pengaruh positif Ease of Use terhadap Customer Perceived Value

\section{TELAAH PUSTAKA}

\section{Customer Perceived Value}

Kotler-Keller (2016:151), "Nilai yang dirasakan pelanggan (CPV) adalah perbedaan antara evaluasi calon pelanggan dari semua manfaat dan biaya dari penawaran dan alternatif yang dirasakan." Kotler-Amstrong (2016: G3), "Nilai yang dipersepsikan pelanggan adalah evaluasi pelanggan atas perbedaan antara semua manfaat dan semua biaya dari penawaran pemasaran relatif terhadap tawaran yang bersaing." Zeithaml dalam Cevik Şimşek, dan Mittal (2016:184) nilai yang dirasakan oleh pelanggan didefinisikan sebagai penilaian dari keseluruhan oleh konsumen terhadap kegunaan suatu produk berdasarkan persepsi tentang apa yang diterima.

Dimensi perceived value menurut Ding dan Tseng (2016:146), yaitu: (1) Functional value terkait dengan kinerja atau utilitas yang dirasakan dari produk 

http://doi.org/10.21009/JRMSI

atau layanan (selanjutnya di sebut sebagai 'penawaran'), yaitu kemampuan intrinsik penawaran untuk memenuhi fungsi yang diciptakan untuk menyediakan, serta manfaat yang terkait dengan kepemilikan penawaran; (2) Social value adalah utilitas yang dirasakan yang di peroleh dari asosiasi alternatif dengan satu atau lebih kelompok sosial tertentu; (3) Emotional value merupakan utilitas yang dirasakan yang di peroleh dari kapasitas alternatif untuk membangkitkan emosi dan perasaan positif, atau keadaan afektif dengan cara yang konstruktif. Misalnya kapasitas desain beberapa restoran dalam merangsang perasaan; (4) Epistemic value utilitas yang dirasakan untuk membangkitkan rasa ingin tahu, nmemberikan kebaruan dan memenuhi keinginan misal mencari pengetahuan karena bosan dengan merek yang dibeli sebelumnya, atau hanya sebagai bagian dari pencarian variasi, seperti keinginan untuk mencoba sarapan sereal yang berbeda; (5) Dengan menambahkan satu dimensi dari Cassia, Ugolini, Cobelli, dan Gill (2016:250), Price value yaitu utilitas yang berasal dari seberapa puas suatu produk dibandingkan dengan biaya, waktu, dan upaya untuk mendapatkan produk.

\section{Brand Awareness}

Hoyer dan Brown dalam Huang dan Sarigöllü (2012:93) "Merek yang dikenal cenderung memiliki peluang untuk dipilih konsumen" Aaker dalam Kim, Jin-Sun, dan Kim (2008:237) menyatakan "Brand awareness sebagai kekuatan kehadiran merek di benak pelanggan. Durianto, Sugiarto dan Budiman (2004: 81) menjelaskan bahwa merek berfungsi untuk membentuk identitas sehingga mudah di kenal dan dibedakan dengan kompetitor serta menjadi tolak ukur kekuatan merek agar tidak mudah di serang oleh kompetitor.

Dimensi brand awareness menurut Ding dan Tseng (2015:106), yaitu: (1) Brand recognition yaitu kemampuan mengenali merek di antara merek pesaing; (2) Brand recall yaitu kemampuan untuk cepat mengingat simbol atau logo merek; (3) Top of mind yaitu kemampuan mengidentifikasi karakteristik merek muncul di benak dengan cepat.

\section{Product Quality}

ASQ dalam Hidayat (2007:3) yaitu karakteristik produk maupun jasa di lihat dari kemampuan produk atau jasa dalam memberikan nilai pada kebutuhan 
harapan dan kepuasan konsumen suatu produk atau jasa bebas dari nilai defisiensi yaitu pemberian pelayanan total kepada konsumen secara konsisten di mulai dari pra penjualan hingga pasca penjualan. Korkman dalam Sudarso (2016:77) bahwa manfaat berasal dari pertemuan kebutuhan yang terpenuhi atau potensial yang ditawarkan oleh pasar, pengorbanan yang diberikan oleh pelanggan untuk mendapatkan penawaran dari pasar bisa secara fisik uang atau usaha nilai dapat di lihat sebagai sesuatu yang di dapat dari pengalaman pelanggan berdasarkan pendekatan teoritis.

Dimensi product quality menurut Kotler dan Keller (2016:394), yaitu: (1) Form yaitu produk dapat dibedakan dalam ukuran, bentuk, atau struktur fisik suatu produk; (2) Performance adalah kualitas kinerja adalah tingkat seperti karakteristik utama produk beroperasi (rendah, rata-rata, tinggi, atau superior) sesuai dengan target pasar dan persaingan; (3) Features adalah manfaat tambahan pelengkap fungsi dasar. Perusahaan dapat mengidentifikasi dan memilih fitur baru yang sesuai kinerja produk aslinya dan sesuai kebutuhan dan keinginan konsumen serta menghemat biaya produksi dan inventaris; (4) Reliability adalah ukuran probabilitas bahwa suatu produk tidak akan gagal berfungsi atau gagal dalam jangka waktu tertentu.

Selain itu (5) Conformance adalah kualitas kesesuaian/sejauh mana semua unit yang diproduksi identik dan memenuhi spesifikasi yang dijanjikan; (6) Durability ketahanan/ukuran kehidupan pengoperasian produk dalam kondisi normal maupun tidak normal; (7) Repairability mengukur kemudahan memperbaiki produk saat tidak berfungsi atau gagal. Perusahaan akan memberikan layanan perbaikan atau cara memperbaiki kerusakan pada pelanggan; (8) Style menggambarkan tampilan dan nuansa produk kepada pembeli dan menciptakan kekhasan yang sulit untuk di salin sesuai nilai estetika; (9) Customization yaitu memungkinkan perusahaan mengimplementasikan penyesuaian produk dan pemasaran yang unik/berbeda dengan mencari.

\section{Ease of Use}

Davis dalam Wang (2014:141) menjelaskan bahwa perceived ease of use pada penggunaannya berdampak signifikan pada niat pengguna untuk menggunakan 
sesuatu. Sedangkan menurut Bruner and Kumar dalam Kulviwat (2007:1063) menjelaskan bahwa sikap memediasi, efek dari kegunaan yang dirasakan, kemudahan penggunaan dan emosi (kesenangan) pada niat.

Dimensi Ease of use oleh Bresciani and Eppler (2015: 51): (1) Easy to learn Sangat mudah untuk mulai berinteraksi secara efektif dengan format visualisasi; (2) Controllable Visualisasi dapat berinteraksi dengan dan parameter dapat dengan mudah di ubah; (3) Clear and understandable Pengetahuan sebelumnya tidak diperlukan untuk menggunakan visualisasi; (4) Flexible The visualization mudah dimanipulasi dan disesuaikan dengan tujuan tertentu; (5) Easy to become skillful visualisasi informasi dapat digunakan dengan potensi penuhnya dengan cepat; (6) Easy to use/understand visualisasi dapat digunakan dengan upaya kognitif terbatas. Maka dari itu penulis menyajikan kerangka teori dalam diagram sebagai berikut:

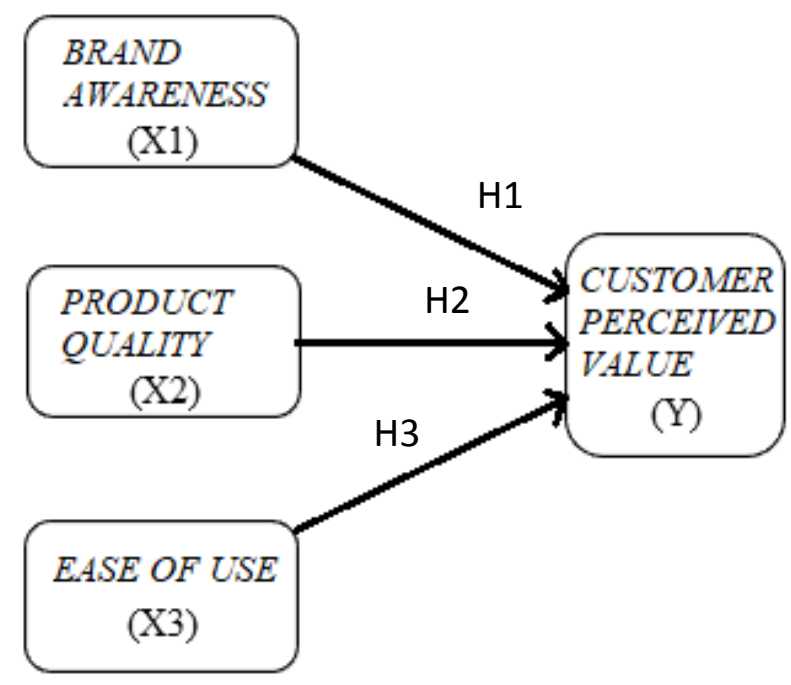

Sumber: Data yang diolah peneliti

\section{Gambar 1. Kerangka Teoritik}

Berdasarkan keterangan diatas maka dapat di tarik hipotesis yaitu:

H1: Brand Awareness berpengaruh positif pada Customer perceived value.

H2: Product Quality berpengaruh positif pada Customer perceived value.

H3: Ease of Use berpengaruh positif pada Customer perceived value.

\section{METODE PENELITIAN}


Penelitian ini menggunakan pendekatan kuantitatif, dengan metode survey kepada responden yang telah ditentukan yaitu pengguna E-Money Mandiri E-Toll Card di wilayah JABODETABEK dengan usia $\geq 17$ tahun terutama pengguna jalan toll. Menurut Sugiyono (2016) rumusan masalah pada penelitian ini adalah Deskriptif-Asosiatif yaitu, suatu rumusan masalah yang berkenaan dengan pertanyaan terhadap keberadaan variabel mandiri, baik hanya pada satu variabel atau lebih yang bersifat menanyakan hubungan antara dua variabel atau lebih.

\section{Populasi dan Sampel}

Responden yang dipilih berdasarkan Non-Probability-Purposive Sampling, maksudnya peneliti tidak memberikan peluang kepada seluruh anggota populasi untuk menjadi narasumber. Namun, telah menentukan populasi berdasarkan kriteria tertentu untuk di pilih mejadi sampel. Berkesesuaian dengan pendapat Teddlie dan Tashakkori (2009: 186).

Syarat responden yang harus dienuhi adalah pengguna E-Money Mandiri EToll Card di wilayah JABODETABEK dengan usia $\geq 17$. Penyebaran kuesioner secara langsung pada pengguna dan online melalui google form.

\section{Teknik Pengumpulan Data}

Sumber data dalam penelitian ini menggunakan data primer dan sekunder. Data primer yaitu data yang di peroleh langsung dari narasumber atau responden tanpa perantara. Data sekunder yang menurut Sugiyono (2016: 225) merupakan sumber data yang tidak langsung memberikan data kepada pengumpul data, misalnya melalui orang lain atau lewat dokumen.

Skala yang digunakan dalam penelitian ini adalah adalah skala likert dengan 6 (enam) poin skor untuk menjabarkan pernyataan variabel dalam kuesioner menjadi indikator yang terukur sesuai dengan Renis likert yang sudah ada kurang lebih sekitar 50 tahun yang lalu.

\section{Teknik Analisis Data}

Pada penelitian ini penulis menggunakan model penelitian regresi berganda (Multiple Regression) dengan bantuan aplikasi SPSS (Statistical Package for the Social Sciences).

\section{Uji Validitas}


Bertujuan untuk mengkonfirmasi korelasi yang memiliki tingkat signifikansi antar variabel serta mengetahui valid atau tidaknya kuesioner yang digunakan dalam penelitian menggunakan korelasi Bivariate pearson (product moment).

\section{Uji Reliabilitas}

Uji kemampuan Instrumen untuk mengungkapkan informasi sesuai dengan kenyataan. Penelitian dinyatakan reliabel jika nilai cronbach's alpha $>0.6$.

\section{Analisis Deskriptif}

Analisis deskriptif dilakukan dengan maksud menggambarkan data dari sample yang terkumpul sesuai realita yg ada. Menurut Gani dan Amalia (2015:112 dan 127) asumsi dasar terdiri dari uji linieritas dan uji normalitas dan asumsi klasik terdiri dari uji multikolinieritas dan uji haterokedastisitas.

\section{Asumsi Dasar}

\section{Uji Linieritas}

Untuk memenuhi prasyarat regresi linier atau alanisis korelasi serta mengetahui hubungan antar dua variabel linear atau tidak secara signifikan maka perlu melakukan uji Linieritas. Hal tersebut dapat dilakukan dengan melihat tabel Anova pada SPSS, jika signifikansi dua variabel kurang dari 0,05 maka mempunyai hubungan yang linear.

\section{Uji Normalitas}

Uji normalitas dilakukan pada model regresi untuk menguji adanya variabel pengganggu/residual memiliki distribusi normal. Pengujian dengan Kolmogorovsmirnov test pada SPSS, jika data terdistribusi normal taraf signifikansi sebesar 0,005 .

\section{Asumsi Klasik}

\section{Uji Multikolinieritas}

Model regresi yang bagus variabel independen tidak berkolerasi satu dengan yang lain. (Santoso, 2018:377) Maksudnya regresi yang baik mutlak tidak ada masalah multikolinearitas.

Pendektesian Multikolinieritas dengan melihat VIF (Value Inflation Factor) pada model regresi di tabel coefficients. Jika VIF kurang dari 10 dan tolerance 
value lebih dari 0,1 maka variabel tersebut tidak memiliki masalah dan tidak terjadi multikolinearitas.

\section{Uji Heteroskedastisitas}

Santoso (2018:376) Residu yang ada (yang baik) seharusnya memiliki varians yang konstan (Homokedastisitas). Jika varians semakin meningkat atau menurun dangan pola tertentu di sebut Heteroskedastisitas.

\section{Uji Hipotesis}

\section{Uji t}

Berfungsi untuk mengetahui pengaruh signifikansi model regresi variabel independen $(\mathrm{X} 1, \mathrm{X} 2, \ldots \mathrm{Xn})$ terhadap variabel dependen $(\mathrm{Y})$. Jika signifikansi kurang dari 0,05 maka variabel bebas tersebut dinyatakan mempengaruhi Variabel terikat

\section{Koefisien Determinasi $\left(\mathbf{R}^{2}\right)$}

Fungsi analisis determinasi untuk mengetahui besaran persentase pengaruh variabel independen terhadap variabel dependen. Jika $\mathrm{R}^{2}=0$ artinya tidak ada sedikitpun persentase variabel independen kepada dependen, jika $\mathrm{R}^{2}=1$ maka persentase yang diberikan sempurna atau $100 \%$. Hasil yang digunakan $\mathrm{R}^{2}$ pada regresi berganda di rasa tidak mampu menjelaskan Degree of freedom.

\section{HASIL DAN PEMBAHASAN}

\section{Deskripsi Data}

Untuk memastikan bahwa responden memenuhi kriteria yang diperlukan, sebelum lebih jauh memberikan pertanyaan dalam survey maka peneliti melakukan Filter Question pada awal kuesioner. Lalu responden dikategorikan dalam 4 bagian, yaitu, Pekerjaan, Penghasilan perbulan,Jumlah per-top up kartu E-toll, dan Intensitas top up kartu E-toll perbulan.

\section{Hasil Analisis Data}

\section{Hasil Uji Validitas}

Hasil uji yang dilakukan pada 30 maupun 200 responden menyatakan bahwa hasil pengujian valid untuk dengan tingkat signifikansi 5\% karena $r_{\text {hitung }}>r_{\text {tabel }}$.

\section{Hasil Uji Reliabilitas}


Hasil uji menyatakan maka instrumen penelitian reliabel karena Cronbach's Alpha lebih dari 0,600 .

\section{Uji Asumsi Dasar}

\section{Uji Linieritas}

Tabel 5. Hasil Uji Linieritas Variabel Brand Awareness (X1) dengan Customer Perceived Value (Y)

\begin{tabular}{|c|c|c|c|c|c|c|c|}
\hline \multicolumn{8}{|c|}{ ANOVA Table } \\
\hline \multirow{6}{*}{$\begin{array}{l}\mathrm{CPV} * \\
\mathrm{BA}\end{array}$} & \multirow{4}{*}{$\begin{array}{l}\text { Between } \\
\text { Groups }\end{array}$} & & $\begin{array}{l}\text { Sum of } \\
\text { Squares }\end{array}$ & df & $\begin{array}{l}\text { Mean } \\
\text { Square }\end{array}$ & $\mathrm{F}$ & Sig. \\
\hline & & (Combined) & 3704.921 & 20 & 185.246 & 11.149 & .000 \\
\hline & & Linearity & 3153.929 & 1 & 3153.929 & 189.825 & .000 \\
\hline & & $\begin{array}{l}\text { Deviation from } \\
\text { Linearity }\end{array}$ & 550.992 & 19 & 29.000 & 1.745 & .033 \\
\hline & Within Groups & & 2974.074 & 179 & 16.615 & & \\
\hline & Total & & 6678.995 & 199 & & & \\
\hline
\end{tabular}

Sumber: Data di olah oleh Peneliti (2018)

Menurut tabel 5 signifikansi baik BA terhadap CPV adalah 0,000. Yaitu variabel Brand Awareness, Product quality serta Ease of Use terhadap Customer Perceived Value memiliki hubungan yang linier.

Tabel 6. Hasil Uji Linieritas Variabel Product quality (X2) dengan Customer Perceived Value (Y)

\begin{tabular}{|c|c|c|c|c|c|c|}
\hline \multicolumn{7}{|c|}{ ANOVA Table } \\
\hline & & & Sum of & & Mean & \\
\hline & & & Squares & df & Square & Sig. \\
\hline $\mathrm{CPV} *$ & Between & (Combined) & 4354.170 & 73 & 59.646 & 3.233 .000 \\
\hline \multirow[t]{5}{*}{ PQ } & Groups & Linearity & 2293.363 & 1 & 2293.363 & 24.295 .000 \\
\hline & & Deviation from & 2060.807 & 72 & 28.622 & 1.551 .016 \\
\hline & & Linearity & & & & \\
\hline & Within Groups & & 2324.825 & 126 & 18.451 & \\
\hline & Total & & 6678.995 & 199 & & \\
\hline
\end{tabular}

Sumber: Data di olah oleh Peneliti (2018)

Menurut tabel 6 signifikansi PQ terhadap CPV adalah 0,000. Yaitu variabel Brand Awareness, Product quality serta Ease of Use terhadap Customer Perceived Value memiliki hubungan yang linier. 
Tabel 7. Hasil Uji Linieritas Variabel Ease of Use (X3) dengan Customer Perceived Value (Y)

\begin{tabular}{|c|c|c|c|c|c|c|}
\hline \multicolumn{7}{|c|}{ ANOVA Table } \\
\hline & & & Sum of & & Mean & \\
\hline & & & Squares & df & Square & Sig. \\
\hline $\mathrm{CPV} *$ & Between & (Combined) & 3561.233 & 25 & 142.449 & 7.950 .000 \\
\hline \multirow[t]{5}{*}{ EOU } & Groups & Linearity & 3065.176 & \multicolumn{3}{|c|}{13065.176171 .065 .000} \\
\hline & & Deviation from & 496.057 & 24 & 20.669 & 1.154 .292 \\
\hline & & Linearity & & & & \\
\hline & Within Groups & & 3117.762 & 174 & 17.918 & \\
\hline & Total & & 6678.995 & 199 & & \\
\hline
\end{tabular}

Sumber: Data di olah oleh Peneliti (2018)

Menurut tabel 7 signifikansi EoU terhadap CPV adalah 0,000. Yaitu variabel Brand Awareness, Product quality serta Ease of Use terhadap Customer Perceived Value memiliki hubungan yang linier.

\section{Uji Normalitas}

Tabel 8. Hasil Uji Residual

One-Sample Kolmogorov-Smirnov Test

\begin{tabular}{llr}
\hline & & Unstandardized Residual \\
\hline $\mathrm{N}$ & & 200 \\
Normal Parameters ${ }^{\mathrm{a}, \mathrm{b}}$ & Mean & .0000000 \\
& Std. Deviation & 3.59867623 \\
Most Extreme Differences & Absolute & .040 \\
& Positive & .040 \\
& Negative & -.039 \\
Kolmogorov-Smirnov Z & & .564 \\
Asymp. Sig. (2-tailed) & & .908 \\
\hline a. Test distribution is Normal. & \\
b. Calculated from data. & \\
\multicolumn{2}{l}{ Sumber: Data di olah oleh Peneliti (2018) }
\end{tabular}

Baik uji yang dilakukan pervariabel maupun unstandardized residual pada kolmogrof smirnov data menunjukkan model regresi berdistribusi normal.

\section{Uji Multikolinieritas}


Tabel 9. Hasil Uji Multikolinearitas

\begin{tabular}{clll}
\multicolumn{3}{c}{ Coefficients $^{\mathrm{a}}$} \\
\hline Model & Tolerance & VIF \\
\hline 1 BA & .641 & 1.560 \\
PQ & .586 & 1.706 \\
EOU & .553 & 1.810
\end{tabular}

a. Dependent Variable: CPV

Sumber: Data diolah oleh peneliti (2018)

Hasil masing-masing dari keseluruhan variabel kurang dari 10 dan nilai tolerance lebih dari 0,1 dapat disimpulkan bahwa model regresi tidak ditemukan masalah Multikolinearitas.

\section{Uji Heteroskedastisitas}

Tabel 10. Hasil Uji Heteroskedastisitas

\begin{tabular}{|c|c|c|c|c|c|}
\hline \multicolumn{6}{|c|}{ Correlations } \\
\hline & & Unstandardized Residual & \multirow{2}{*}{$\begin{array}{l}\text { BA } \\
.000\end{array}$} & \multirow{2}{*}{$\begin{array}{l}\mathrm{PQ} \\
.000\end{array}$} & \multirow{2}{*}{$\begin{array}{c}\text { EOU } \\
.000\end{array}$} \\
\hline Unstandardized Residual & Pearson Correlation & & & & \\
\hline & Sig. (2-tailed) & & 1.000 & 1.000 & 1.000 \\
\hline & $\mathrm{N}$ & 200 & 200 & 200 & 200 \\
\hline \multirow[t]{3}{*}{$\mathrm{BA}$} & Pearson Correlation & .000 & 1 & $.516^{* *}$ & $.555^{* *}$ \\
\hline & Sig. (2-tailed) & 1.000 & & .000 & .000 \\
\hline & $\mathrm{N}$ & 200 & 200 & 200 & 200 \\
\hline \multirow[t]{3}{*}{ PQ } & Pearson Correlation & .000 & $.516^{* *}$ & & $.606^{* *}$ \\
\hline & Sig. (2-tailed) & 1.000 & .000 & & .000 \\
\hline & $\mathrm{N}$ & 200 & 200 & 200 & 200 \\
\hline \multirow[t]{3}{*}{ EOU } & Pearson Correlation & .000 & $.555^{* *}$ & $.606^{* *}$ & 1 \\
\hline & Sig. (2-tailed) & 1.000 & .000 & .000 & \\
\hline & $\mathrm{N}$ & 200 & 200 & 200 & 200 \\
\hline
\end{tabular}

**. Correlation is significant at the 0.01 level (2-tailed)

Sumber: Data diolah oleh peneliti (2018)

Uji yang dilakukan menggunakan spearman's rho, dapat diketahui nilai sig. masing-masing variabel lebih 0,05 sehingga dapat dikatakan tidak ada masalah Heteroskedastisitas.

\section{Uji Hipotesis}


Tabel 11. Hasil Uji Linier Berganda

\section{Coefficients $^{\mathrm{a}}$}

\begin{tabular}{lrccrr}
\hline \multicolumn{5}{c}{ Unstandardized Coefficients Standardized Coefficients } \\
Model & B & Std. Error & Beta & t & Sig. \\
\hline 1 (Constant) & 10.205 & .968 & & 10.537 .000 \\
BA & .441 & .060 & .408 & 7.358 .000 \\
PQ & .050 & .018 & .162 & 2.788 .006 \\
EOU & .315 & .053 & .353 & 5.917 .000 \\
\hline
\end{tabular}

Dependent Variable: CPV

Sumber: Data diolah oleh peneliti (2018)

Berdasarkan hasil pada variabel BA, PQ dan EOU 0 maka nilai konstanta adalah 10.205.Koefisien regresi BA 0,441 artinya jika variabel BA mengalami kenaikan satu-satuan sementara variabel PQ dan EOU tetap maka nilai CPV akan mengalami kenaikan sebesar 0,441. Karena koefisien bernilai positif maka terdapat pengaruh positif BA terhadap CPV. Koefisien regresi PQ 0,050 artinya jika variabel PQ mengalami kenaikan satu-satuan sementara variabel BA dan EOU tetap maka nilai CPV akan mengalami kenaikan sebesar 0,050. Karena koefisien bernilai positif maka terdapat pengaruh positif PQ terhadap CPV. Koefisien regresi EOU 0,315 artinya jika variabel EOU mengalami kenaikan satusatuan sementara variabel BA dan PQ tetap maka nilai CPV akan mengalami kenaikan sebesar 0,315. Karena koefisien bernilai positif maka terdapat pengaruh positif EOU terhadap CPV.

\section{Uji t}

Tabel 12. Hasil Uji tCoefficients ${ }^{\mathrm{a}}$

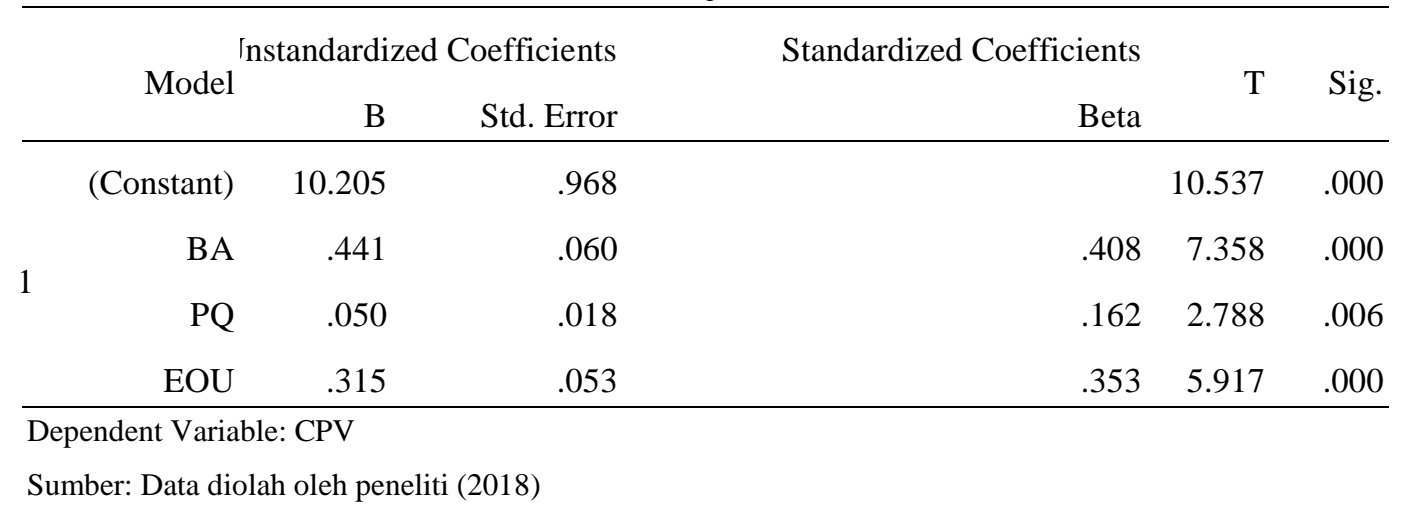


Dapat diketahui nilai sig. $<0,05$ dan jika dibandingkan dengan nilai $t_{\text {tabel }}$ $1.971, \mathrm{t}_{\text {hitung }}$ lebih besar. Maka variabel brand awareness, product quality, dan ease of use mempengaruhi customer perceived value secara signifikan.

Koefisien Determinasi $\left(\mathbf{R}^{2}\right)$

Tabel 13. Hasil Uji Adj $\mathbf{R}^{2}$

Model Summary

Model R R Square Adjusted R Square Std. Error of the Estimate

\begin{tabular}{llll}
\hline 1 & $.784^{\mathrm{a}}$ & .614 & .608
\end{tabular}

a. Predictors: (Constant), EOU, BA, PQ

b. Dependent Variable: CPV

Sumber: Data diolah oleh peneliti (2018)

Nilai Adj $\mathrm{R}^{2}$ adalah 0,608 artinya sumbangan variabel BA, PQ, EOU sebesar $60,8 \%$ sedangkan sisanya sebesar 39,2\% dijelaskan oleh faktor lain yang tidak di teliti (misal. Variabel brand image, service quality, customer experience dan lainnya). Hasil penelitian ini mampu memenuhi tujuan peneliti untuk mengetahui adanya pengaruh variabel brand awareness, product quality dan ease of use terhadap customer perceived value.

\section{KESIMPULAN DAN SARAN}

\section{Kesimpulan}

Pernyataan Hipotesis satu (H1) diterima atau Brand Awareness berpengaruh positif - signifikan pada Customer perceived value, sedangkan pernyataan Hipotesis kedua (H2) diterima atau Product Quality berpengaruh positif signifikan pada Customer perceived value, dan pernyataan Hipotesis ke-tiga (H3) diterima atau Ease of Use berpengaruh positif - signifikan pada Customer perceived value.

\section{Saran}

Gencarkan lebih baik lagi promosi dari brand secara verbal melalui media elektronik, media cetak, sosial media, dan perusahaan juga dapat melakukan promosi dengan tema yang menarik dan edukatif. Kemudian tingkatkan kualitas produk dengan menggunakan struktur material yang kuat, elastis dan tahan terhadap panas sehingga tidak mudah bengkok, lalu pada fasilitas penunjang (alat 
card reader pada GTO) perusahaan diharapkan dapat meningkatkan sistem yang upgrade dan selalu di cek secara berkala, juga sediakan petugas ahli, dan yang terakhir adalah tingkatkan sosialisasi dan tutorial kemudahan dalam penggunaan uang elektronik dari E-money Mandiri E-toll card melalui sosial media baik berupa video singkat maupun berupa tulisan, dan juga penjelasan kemudahan dari produk melalui spg. Sehingga menimbulkan pengalaman menarik bagi pelanggan dan pelanggan dapat merasakan manfaat dari penggunaan produk.

\section{DAFTAR PUSTAKA}

Bank Sentral Republik Indonesia. (2017). Instrumen Pembayaran Nontunai. Retrieved from Bank Sentral Republik Indonesia: https://www.bi.go.id/id/sistem-pembayaran/instrumennontunai/unik/Contents/Default.aspx

Bresciani, S., \& Eppler, M. J. (2015). Extending Tam to Information Visualization: A Framework for Evaluation. The Electronic Journal of Information Systems Evaluation, 18(1), 46-58.

Cassia, F., Ugolini, M. M., Cobelli, N., \& Gill, L. (2015). Service-based vs. goods-based positioning of the product concept: effects on customer perceived value. The TQM Journal, 27(2), 247-255.

Çevik, S., Şimşek, H., \& Mittal, H. (2016). Social \& Economic Dynamics of Development: Case Studies. United Kingdom: IJOPEC Publication.

Çifci, S., Ekinci, Y., Whyatt, G., Japutra, A., Molinillo, S., \& Siala, H. (2016). A cross validation of Consumer-Based Brand Equity models: Driving customer equity in retail brands. Journal of Business Research, 69(9), 3740-3747.

Delaporte, T., Price, P., \& Bastid, V. (2017). The World FinTech Report 2017. Retrieved from Capgemini: www.capgemini.com/wpcontent/uploads/2017/09/world_fintech_report_2017.pdf 
Ding, C. G., \& Tseng, T. H. (2015). On the Relationships Among Brand Experience, Hedonic Emotions, and Brand Equity. European Journal of Marketing, 28, 57-73.

Firmansyah, F., \& Susanto, E. (2017, October 31). Hari Ini E-Toll Berlaku Serentak, 5 Kelemahannya. Retrieved from Tempo: https://bisnis.tempo.co/read/1029262/hari-ini-e-toll-berlaku-serentak-5kelemahannya

Gani, I., \& Amalia, S. (2015). ALAT ANALISIS DATA: Aplikasi Statistik Untuk Penelitian Bidang Ekonomi dan Sosial. Yogyakarta: Andi.

Insights Association. (2018). Filter Question. Retrieved from Insights Association: $\quad$ https://www.insightsassociation.org/issuespolicies/glossary/filter-question

Kim, E. Y., Knight, D. K., \& Pelton, L. E. (2009). Modeling Brand Equity of a U.S. Apparel Brand as Perceived by Generation Y Consumers in the Emerging Korean Market. Clothing \& Textiles Research Journal, 27(4), 247-258.

Kim, W. G., Jin-Sun, B., \& Kim, H. J. (2008). Multidimensional Customer-Based Brand Equity and Its Consequences in Midpriced Hotel. Journal of Hospitality \& Tourism Research, 32(2), 235-254.

Kotler, P., \& Armstrong, G. (2016). Principles of marketing. USA: Pearson.

Kotler, P., \& Keller, K. L. (2016). Marketing management. England: Pearson.

Kulviwat, S., Bruner, G. C., Kumar, A., Nasco, S. A., \& Clark, T. (2007). Toward a Unified Theory of Consumer Acceptance Technology. Psychology \& Marketing, 24(12), 1059-1084.

Mandiri. (2017). Mandiri E-Money. Retrieved from Mandiri: https://www.bankmandiri.co.id/e-money 
Purnamasari, D. (2017, October 26). 50,90\% Masyarakat Khawatirkan Penggunaan Data e-Money. Retrieved from tirto.id: https://tirto.id/5090masyarakat-khawatirkan-penggunaan-data-e-money-cy41

Santoso, S. (2018). Menguasai Statistik Dengan SPSS 25. Jakarta: Elex Media Komputindo.

Sugiyono. (2016). Metode Penelitian Manajemen. Bandung: Alfabeta.

Top Brand Award. (2018). Top Brand Index 2018 Fase 1. Retrieved from Top Brand Award: http://topbrand-award.com/top-brand-survey/surveyresult/top_brand_index_2018_fase_1

Wibowo, S. F., Rosmauli, D., \& Suhud, U. (2015). Pengaruh persepsi Manfaat, Persepsi Kemudahan, Fitur Layanan, dan Kepercayaan Terhadap Minat Menggunakan E-Money Card (Studi Pada Pengguna Jasa Commuterline Di Jakarta). Jurnal Riset Manajemen Sains Indonesia. 